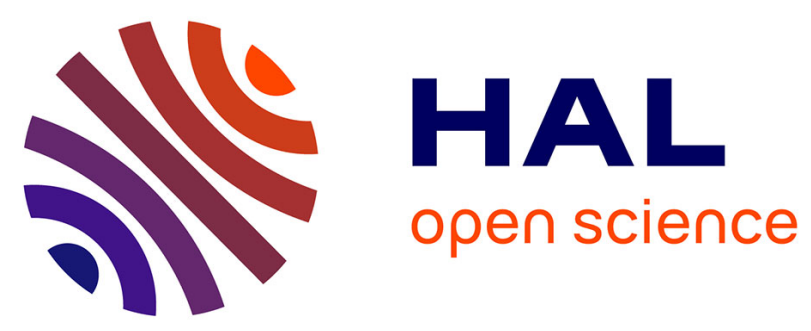

\title{
Partial characterisation of peptides inhibiting Listeria growth in two Alpine cheeses
}

Phuong Nguyen Thi, Coralie Dupas, Isabelle Adt, Pascal Degraeve, Mélanie

Ragon, May-Farah Missaoui, Enrico Novelli, Severino Segato, Dong Phan The, Nadia Oulahal

\section{To cite this version:}

Phuong Nguyen Thi, Coralie Dupas, Isabelle Adt, Pascal Degraeve, Mélanie Ragon, et al.. Partial characterisation of peptides inhibiting Listeria growth in two Alpine cheeses. Dairy Science \& Technology, 2013, 94 (1), pp.61-72. 10.1007/s13594-013-0141-6 . hal-01234845

\section{HAL Id: hal-01234845 \\ https://hal.science/hal-01234845}

Submitted on 27 Nov 2015

HAL is a multi-disciplinary open access archive for the deposit and dissemination of scientific research documents, whether they are published or not. The documents may come from teaching and research institutions in France or abroad, or from public or private research centers.
L'archive ouverte pluridisciplinaire $\mathbf{H A L}$, est destinée au dépôt et à la diffusion de documents scientifiques de niveau recherche, publiés ou non, émanant des établissements d'enseignement et de recherche français ou étrangers, des laboratoires publics ou privés. 


\title{
Partial characterisation of peptides inhibiting Listeria growth in two Alpine cheeses
}

\author{
Phuong Nguyen Thi • Coralie Dupas • Isabelle Adt • \\ Pascal Degraeve • Mélanie Ragon • \\ May-Farah Missaoui • Enrico Novelli • \\ Severino Segato • Dong Phan The • Nadia Oulahal
}

Received: 5 March 2013 / Revised: 4 June 2013 / Accepted: 6 June 2013 /

Published online: 25 June 2013

(C) INRA and Springer-Verlag France 2013

\begin{abstract}
Listeria monocytogenes, agent of food-borne listeriosis, is a major concern in dairy industry. The aim of this study was to assess the occurrence of peptides inhibiting Listeria spp. growth in two traditional Alpine pressed-curd cheeses: Emmental de Savoie and Asiago d'Allevo, and to get further insights regarding the characteristics of these peptides. Water-soluble extracts of these two cheeses were ultrafiltered onto 10,000-g.mol ${ }^{-1}$ cut-off filters to remove proteins and the corresponding filtrate was subsequently dialysed with $100-500-\mathrm{g} \cdot \mathrm{mol}^{-1}$ cut-off membranes to remove salt and organic acids. A decrease from $53 \pm 2 \%$ to $68 \pm 1 \%$ of Listeria innocua LRGIA01 cells growth after $12-\mathrm{h}$ incubation at $30^{\circ} \mathrm{C}$ was observed in the presence of lyophilised extracts of the four cheese samples which were analysed. A less pronounced inhibition of $L$. monocytogenes 162 strain cells growth by cheese extracts was observed under the same conditions. After ultrafiltration onto 1,000 g.mol ${ }^{-1}$ cut-off membranes, all the extracts had almost the same anti-L. innocua activity, suggesting that most of antibacterial
\end{abstract}

P. Nguyen Thi $\cdot$ C. Dupas $•$ I. Adt $\cdot$ P. Degraeve $\cdot$ M. Ragon $\cdot$ M.-F. Missaoui $・$ N. Oulahal $(\bowtie)$ Université Lyon 1, Laboratoire de Bioingénierie et Dynamique Microbienne aux Interfaces Alimentaires (BioDyMIA, Equipe Mixte d’Accueil Université Lyon 1 -ISARA Lyon n³733), Technopole Alimentec, rue Henri de Boissieu, 01000 Bourg en Bresse, France e-mail: nadia.oulahal@univ-lyon1.fr

P. Nguyen Thi $\cdot$ D. Phan The

Faculty of Food Science and Technology, Nông Lâm University, Ho Chi Minh Ville, Vietnam

E. Novelli $\cdot$ S. Segato

Department of Comparative Biomedicine and Food Science, University of Padova, Padova, Italy

E. Novelli $\cdot$ S. Segato

Department of Animal Medicine, Production and Health, University of Padova, Padova, Italy 
peptides had a molecular mass between 100-500 and 1,000 g.mol ${ }^{-1}$. The assay of the anti- $L$. innocua activity of fractions of Asiago cheese extracts separated by cation-exchange chromatography indicated that non-cationic peptides had a lower antibacterial activity. Taken together, these data suggest that most of antibacterial peptides present in Asiago cheese are low molecular mass and cationic peptides. A significant contribution of intact bacteriocins is thus unlikely; a contribution of either antimicrobial fragments of bacteriocins or caseins released by proteolytic enzymes during cheese ripening is more likely.

Keywords Cheese ripening - Antimicrobial peptides · Antilisterial activity $\cdot$ Listeria innocua $\cdot$ Listeria monocytogenes

\section{Introduction}

Fermentation is a traditional method for food preservation. This is one of the reasons why the shelf life of cheeses is longer than that of raw milk. In combination with water activity reduction resulting from draining of cheese whey, salt addition and drying during cheese ripening, the action of microorganisms present in cheese curd is well-known to contribute to cheese preservation. Most of the corresponding mechanisms (i.e. competition for nutrients, production of antimicrobial metabolites such as lactic acid) are well described. However, some additional less well established mechanisms, such as antimicrobial peptides release during cheese ripening, have been proposed to also play a role in cheese as well as in human health preservation. These antimicrobial peptides can be bacteriocins directly produced by lactic acid bacteria (Rodriguez et al. 1998) as well as antimicrobial fragments from milk proteins. The presence of casein fragments inhibiting the growth of food-borne pathogenic or food spoilage bacteria has increasingly been reported in recent years in several cheeses: Pecorino Romano, Canestrato Pugliese, Crescenza, Caprino del Piemonte (Rizzello et al. 2005), commercial Australian Cheddar (Pritchard et al. 2010) and Asiago (Lignitto et al. 2012). The liberation as well as the degradation into inactive fragments of these antimicrobial casein fragments during cheese ripening can result from the action of proteolytic enzymes from milk, rennet or microorganisms (Gobbetti et al. 2002; Silva and Malcata 2005). Rizzello et al. (2005) suggested that the absence of peptides inhibiting L. innocua DSM20649 growth in ParmigianoReggiano, Fossa and Gorgonzola cheeses is due to the higher level of proteolysis in these cheeses which led to their degradation. Since the presence of antimicrobial peptides may vary from one cheese sample to another, namely as a function of their proteolysis index, the anti-Listeria activity of peptides extracted from three Emmental de Savoie cheese samples was first assessed. The anti-Listeria activity of peptides extracted from one Asiago cheese sample (chosen for its high anti-Listeria activity) ripened for 5 months was also determined. The main goal of the present study was to get further insight in the structural characteristics of peptides inhibiting Listeria spp. growth present in hard cheeses: the contribution of peptides with a molecular mass lower than 1,000 g.mol ${ }^{-1}$ to the cheese extracts anti-Listeria activity was thus determined and the anti-Listeria activity of different cation-exchange chromatography fractions of an Asiago cheese extract was assayed in order to assess the contribution of cationic peptides. 


\section{Material and methods}

\subsection{Cheeses}

Three Emmental de Savoie (Protected Geographical Indication) (ripened for 97, 114 and 149 days) and one Asiago d'Allevo (Protected Designation of Origin) (ripened for 150 days) cheese samples were collected from different cheesemaking plants in France and Italy, respectively. These cheeses were made following traditional methods from raw milk using calf rennet and lactic acid bacteria starter cultures. Only one Asiago cheese sample was considered, since Lignitto et al. (2012) already studied the influence of the length of Asiago cheeses ripening time on their anti-Listeria activity. In the case of Asiago d'Allevo, a selected strain (T1/A-D, Bioagro Srl, Thiene, Vicenza, Italy) of Streptococcus thermophilus was used as starter (see Segato et al. 2007 for more details). Slices of approximately $250 \mathrm{~g}$ were cut from the centre to the surface of the cheeses (all the cheeses were cylindrical) and were stored at $-18{ }^{\circ} \mathrm{C}$ until their analysis. Prior to their analysis, the slices of each cheese were grated after the rinds were removed and discarded. Total nitrogen (TN) and water-soluble nitrogen (WSN) of cheeses was determined by the Kjeldahl method (AOAC 1984). Prior to WSN determination, the water-soluble fraction of cheeses was prepared as described in Bouton et al. (1993). The proteolysis index of cheeses was calculated as the WSN/TN ratio.

\subsection{Preparation of cheese water-soluble extracts}

Water-soluble extracts (WSEs) of cheeses were prepared according to a previously described procedure (Dupas et al. 2009), with the following modifications: the pH of the initial cheese mixture was adjusted to 2 , to prevent further enzymatic degradation of peptides, and the final filtrates (obtained through 10,000 g.mol ${ }^{-1}$ cut-off polyethersulfone ultrafiltration membranes) were further dialysed for $48 \mathrm{~h}$ at $4{ }^{\circ} \mathrm{C}$ through a 100 500 g.mol ${ }^{-1}$ cut-off cellulose ester membrane (Spectra/Por ${ }^{\circledR}$, Breda, NL) to remove lower molecular mass molecules (such as salt). Salt removal was checked using a chloride analyser (Sherwood Scientific, Cambridge, U.K.), $\mathrm{pH}$ was adjusted to 7.5 (pH for Listeria spp. optimal growth) using $\mathrm{NaOH} 3 \%(w / v)$ and the samples were freezedried and stored at $-20{ }^{\circ} \mathrm{C}$ until used.

The WSEs extracted from each of the four cheese samples were analysed by gel filtration chromatography (GFC). A Perkin Elmer (Norwalk, CT, USA) HPLC system consisting of a binary LC250 pump, a 235C diode array detector, a computer with TotalChrom Navigator ${ }^{\circledR}$ software and a Superdex ${ }^{\circledR}$ Peptide PE 7.5/300 column (Pharmacia Biotech, Uppsala, Sweden) were used. Samples $(0.3 \mathrm{mg}$ of each cheese WSE lyophilisate suspended in $0.1 \mathrm{~mL}$ of water) were loaded onto the column and eluted for $120 \mathrm{~min}$ with $30 \%(\mathrm{v} / \mathrm{v})$ of $0.1 \%(v / v)$ trifluoroacetic acid (TFA) in acetonitrile and 70\% $(v / v)$ of $0.1 \%(v / v)$ TFA in water. The flow rate was $0.25 \mathrm{~mL} \cdot \mathrm{min}^{-1}$, and detection was carried out at $215 \mathrm{~nm}$. The Superdex ${ }^{\circledR}$ Peptide PE 7.5/300 column was calibrated with proteins, peptides, and free amino acids of different molecular masses (cytochrom c (12,500 g.mol ${ }^{-1}$ ), aprotinin (6,511 g.mol $\left.{ }^{-1}\right)$, substance P (1,347 g.mol $\left.{ }^{-1}\right)$, angiotensin-converting enzyme inhibitor $\left(1,101\right.$ g.mol $\left.{ }^{-1}\right)$, Tyr-Lys (327 g.mol ${ }^{-1}$ ), Tyr-Pro (296 g.mol $\left.{ }^{-1}\right)$, Gly-Gly-Gly (189 g.mol $\left.{ }^{-1}\right)$, L-Tyr (204 g.mol $\left.{ }^{-1}\right)$ and L-Trp $\left(181\right.$ g.mol $\left.\left.{ }^{-1}\right)\right)$ as described in Dupas et al. 
(2009). The proportion of molecules with a molecular mass between 200 and 1,000 g. $\mathrm{mol}^{-1}$ was calculated as the ratio between the area under curve (AUC) (plotting of 215-nm absorbance vs. time) of molecules eluted between 32.8 and $41.0 \mathrm{~min}$ (i.e. having a molecular mass lower than 1,000 g.mol ${ }^{-1}$, as deduced from the GFC molecular mass vs. elution time calibration curve) and the total AUC for each cheese WSE and for each cation-exchange chromatography fraction of Asiago cheese extract (see below).

Moreover, a part of cheese WSEs lyophilisates were resuspended in water at a concentration of $40 \mathrm{mg} \cdot \mathrm{mL}^{-1}$ of powder and further fractionated through a 1,000 g.mol ${ }^{-1}$ cut-off membrane (Microsep, Pall Gelman laboratories, Saint-Germain-en-Laye, France). The permeates (containing compounds with a molecular mass lower than 1,000 g.mol ${ }^{-1}$ ) were mixed with an equal volume of double-strength $(2 \times)$ Brain Heart Infusion (BHI) broth and used to assess their respective effects on the growth of Listeria spp.

\subsection{Fractionation of cheese extracts by cation-exchange liquid chromatography}

Asiago cheese WSE was further fractionated by cation-exchange liquid chromatography (CEC). A quantity of $0.5 \mathrm{~g}$ of cheese WSE lyophilisate was first suspended in $50 \mathrm{mmol} . \mathrm{L}^{-1}$ citrate buffer and the $\mathrm{pH}$ was adjusted to 5.2 using $30 \%(w / v) \mathrm{NaOH}$ (final volume $30 \mathrm{~mL}$ ). This preparation was then loaded onto a strong cation-exchanger 15-mL bed volume column (Macro-Prep High S support, Bio-Rad Laboratories, Marnesla-Coquette, France), equilibrated with $50 \mathrm{mmol}^{-1} \mathrm{~L}^{-1}$ citrate buffer, $\mathrm{pH}$ 5.2. The flow rate was $15 \mathrm{~mL} \cdot \mathrm{h}^{-1}$. After 4-h flow-through with $60 \mathrm{~mL}$ citrate buffer, the column was eluted with a 5 -h linear gradient of $0-1 \mathrm{~mol} . \mathrm{L}^{-1} \mathrm{NaCl}$ in citrate buffer. The $215-\mathrm{nm}$ absorbance of eluates was plotted versus elution time and eluates were divided into three fractions according to the plotting depicted in Fig. 1a. The three fractions were dialysed and freezedried, as previously described, and their antimicrobial activities were assayed. The AUC of each of the three fractions was calculated.

\subsection{Bacterial strains and assay of antimicrobial activity}

L. innocua was considered since (1) it can be used as a biological indicator for Listeria monocytogenes because of its similar response to physical, chemical or thermal treatments (Kamat and Nair 1996); (2) it is non-pathogenic in character; and (3) several antimicrobial peptides present in cheeses have been shown to inhibit its growth (Lignitto et al. 2012).

L. monocytogenes strain 162 (serotype 1/2a) and L. innocua LRGIA 01 both isolated from dairy environment (from cheese brine and from a surface, respectively). L. monocytogenes strain 162 was obtained from the Aerial collection (Illkirch, France). Long-term stock cultures were stored at $-80^{\circ} \mathrm{C}$ in a BHI broth supplemented with $15 \%(v / v)$ glycerol.

The antibacterial activities of the cheese WSEs against L. innocua LRGIA 01 strain and L. monocytogenes strain 162 were assayed as follows. To ensure that bacterial growth monitoring was performed in the exponential phase, $9 \mathrm{~mL}$ of BHI broth were inoculated with $1 \mathrm{~mL}$ of the stock culture and incubated at $30{ }^{\circ} \mathrm{C}$ for $8 \mathrm{~h}$. Then, $1 \mathrm{~mL}$ of this first culture was inoculated again with $9 \mathrm{~mL}$ of fresh $\mathrm{BHI}$ broth and incubated overnight. Finally, a third culture was made from the second one (same conditions) and its turbidity was monitored at $630 \mathrm{~nm}$ with a Jenway 6300 spectrophotometer (Bibby 


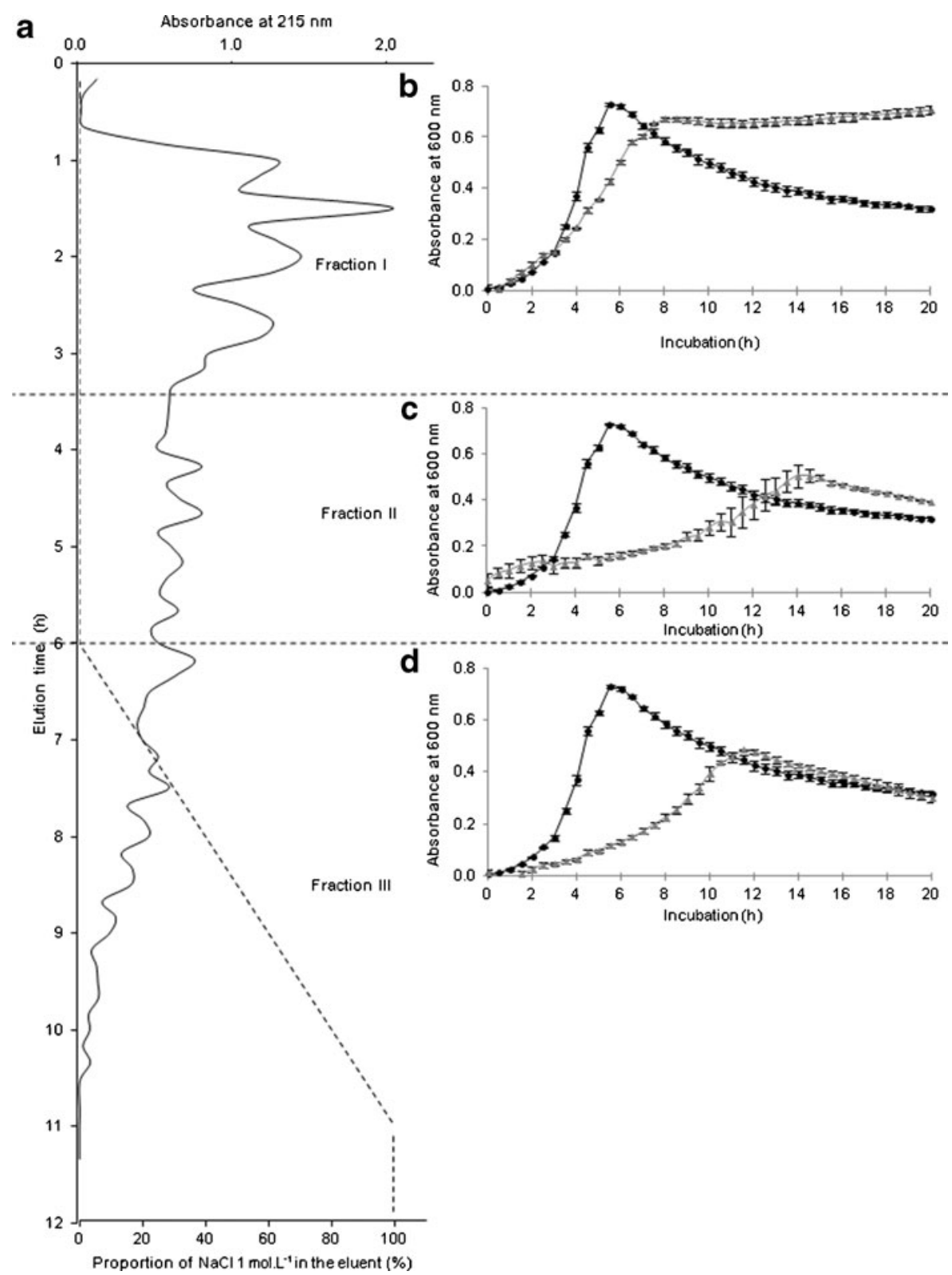

Fig. 1 a Fractionation of Asiago cheese water-soluble extract ripened for 150 days by cation-exchange liquid chromatography (CEC). b, c, d L.innocua growth with (dashed triangle) or without (dashed circle) $20 \mathrm{mg}$ lyophilisate. $\mathrm{mL}^{-1}$ of each peptide fraction obtained following CEC. The results presented are the means \pm standard deviations (error bars) of three replicates

Scientific Ltd., Staffordshire, UK) until the optical density value corresponding to $10^{6} \mathrm{CFU} . \mathrm{mL}^{-1}$ was reached. For determination of the antibacterial activity, $270 \mu \mathrm{L}$ of BHI broth alone (control) or supplemented with whole WSEs lyophilisates, 1,000-g.mol ${ }^{-1}$ cut-off membranes ultrafiltration permeates of WSEs or freeze-dried CEC fractions of 
Asiago cheese WSE (final concentrations: $20 \mathrm{mg}$ of powder per millilitre of culture medium) were mixed either with $30 \mu \mathrm{L}$ of bacterial inocula or $30 \mu \mathrm{L}$ of sterile BHI broth (control) in each well of the microplate and incubated at $30{ }^{\circ} \mathrm{C}$ for $20 \mathrm{~h}$ in a Bioscreen $\mathrm{C}$ apparatus (Oy Growth Curves AB Ltd., Helsinki, Finland). The optical density of the culture was monitored at $600 \mathrm{~nm}\left(\mathrm{OD}_{600}\right)$. Negative controls wells (containing 2,400 IU.mL ${ }^{-1}$ nisin) were also monitored. Briefly, the $\mathrm{OD}_{600}$ was determined just prior to incubation $\left(\mathrm{t}_{0}\right)$ and again after 12-h incubation $\left(t_{12}\right)$, because $\mathrm{OD}_{600}$ reached its maximal value after $12 \mathrm{~h}$ in control wells. The $\mathrm{OD}_{600}$ for each replicate at $\mathrm{t}_{0}$ was subtracted from the $\mathrm{OD}_{600}$ for each replicate at $t_{12}$. The adjusted $\mathrm{OD}_{600}$ of each control well was then assigned a value of $100 \%$ growth. The percent reduction of $\mathrm{OD}_{600}$ after 12-h incubation was thus determined using the formula:

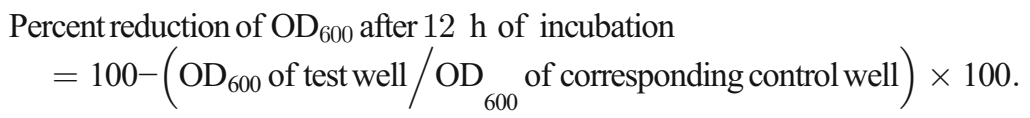

The percent reduction of maximal growth specific rate $(\mu)$ as compared with control wells was also calculated for each cheese extract: $(\mu$ in control well $-\mu$ in test well $) / \mu$ in control well $\times 100$. All the antibacterial activity assays were performed in triplicate and data were given as mean \pm SEM (standard error of the means). The assumption of normal distribution of these data was checked using the Shapiro-Willks test. Differences were tested using a Welch's one-way ANOVA. The level of significance was set at $P=0.05$ for all comparisons.

\section{Results and discussion}

\subsection{Anti-Listeria spp. activity of cheese extracts}

The results concerning the inhibition of Listeria spp. cells growth in the presence of $20 \mathrm{mg}$ of cheese extracts per $\mathrm{mL}$ of BHI broth are presented in Table 1. The three Emmental de Savoie as well as the Asiago cheeses WSEs tested all significantly inhibited L. innocua LRGIA01 strain cells growth: the reductions of maximal specific growth rate and of $\mathrm{OD}_{600}$ after 12 -h incubation at $30{ }^{\circ} \mathrm{C}$ were both significant. $L$. innoсиа LRGIA01 inhibition by Asiago cheese WSEs was also reported by Lignitto et al. (2012). However, to our knowledge, antibacterial activity of Emmental de Savoie cheese extracts has never been observed, although the presence in Emmental cheese of $25 \mathrm{mg}$ per $100 \mathrm{~g}$ of isracidin $\left(\alpha_{\mathrm{s} 1}-\mathrm{CN} \mathrm{f}(1-23)\right)$, an antimicrobial peptide, has been reported by Gagnaire and Léonil (2002). Rizzello et al. (2005) also reported that peptides extracted from Pecorino Romano, Canestrato Pugliese, Crescenza and Caprino del Piemonte cheeses inhibited L. innocua DSM 20649 growth.

Interestingly, Emmental de Savoie cheese WSEs also inhibited L. monocytogenes strain 162 growth, although to a lesser extent than L. innocua LRGIA01. This was also observed with Asiago cheese (Lignitto et al. 2012). In the present study, about $50 \%$ inhibition of L. monocytogenes strain 162 growth was observed when Emmental de Savoie cheese WSE lyophilisates were added at a $20 \mathrm{mg} \cdot \mathrm{mL}^{-1}$ concentration in 
Table 1 Influence of cheese extracts lyophilisates addition on the growth of L. innocua LRGIA01 and $L$. monocytogenes strain 162 growth at $30{ }^{\circ} \mathrm{C}$ in $\mathrm{BHI}$ broth

\begin{tabular}{|c|c|c|c|c|c|}
\hline \multirow{2}{*}{$\begin{array}{l}\text { Cheese } \\
\text { Age (days) }\end{array}$} & & \multirow{2}{*}{$\begin{array}{l}\text { Asiago d'Allevo } \\
150\end{array}$} & \multicolumn{3}{|c|}{ Emmental de Savoie } \\
\hline & & & 97 & 114 & 149 \\
\hline \multirow[t]{2}{*}{ L. innocua LRGIA01 } & $\begin{array}{l}\text { Proportion }(\%) \text { of reduction } \\
\text { of } \mathrm{OD}_{600} \text { after } 12-\mathrm{h} \text { incubation }\end{array}$ & $53 \pm 2^{\mathrm{a}}$ & $56 \pm 1^{\mathrm{a}, \mathrm{b}}$ & $61 \pm 1^{\mathrm{b}}$ & $68 \pm 1^{\mathrm{c}}$ \\
\hline & $\begin{array}{l}\text { Proportion }(\%) \text { of reduction } \\
\text { of growth rate }\end{array}$ & 57 & 44 & 86 & 70 \\
\hline \multirow[t]{2}{*}{$\begin{array}{l}\text { L. monocytogenes } \\
\text { strain } 162\end{array}$} & $\begin{array}{l}\text { Proportion }(\%) \text { of reduction } \\
\text { of } \mathrm{OD}_{600} \text { after } 12-\mathrm{h} \text { incubation }\end{array}$ & n.d. & $45 \pm 6^{\mathrm{a}}$ & $39 \pm 1^{\mathrm{a}}$ & $61 \pm 1^{\mathrm{b}}$ \\
\hline & $\begin{array}{l}\text { Proportion }(\%) \text { of reduction } \\
\text { of growth rate }\end{array}$ & & 70 & 88 & 77 \\
\hline
\end{tabular}

Cheese extracts contain molecules with a molecular mass ranging from $\sim 100-500$ to 10,000 g.mol ${ }^{-1}$

Samples with same letters are not significantly different $(P<0.05)$

n.d. not determined. The results presented are the means of three replicates \pm standard error of the mean

BHI broth. In order to estimate whether this can be of any practical significance, it might be useful to indicate that these compounds are present at $\sim 8$ times higher concentration (i.e. $\sim 150$ g. $\mathrm{L}^{-1}$ ) in the aqueous phase of these cheeses.

Antimicrobial peptides present in Emmental de Savoie as well as Asiago cheese extracts could be bacteriocins as well as antimicrobial fragments of caseins. In order to get information on the size of peptides inhibiting L. innocua growth, the antimicrobial activity of cheese extracts was assayed following their ultrafiltration onto $1,000-\mathrm{g} \cdot \mathrm{mol}^{-1}$ cut-off membranes to remove peptides with a larger molecular mass (Table 2). The relative contribution of peptides with a molecular mass lower than 1,000 g.mol ${ }^{-1}$ to the overall antimicrobial activity of whole cheese extracts was determined by calculating the ratio between the percentage of $\mathrm{OD}_{600}$ reduction after 12 -h incubation at $30{ }^{\circ} \mathrm{C}$ in the presence of each cheese extract filtrate (Table 2) and the corresponding percentage in the presence of each whole cheese extract (Table 1). This allowed thus to estimate that peptides with a molecular mass lower than 1,000 g.mol ${ }^{-1}$ accounted for $100 \pm 2 \%$ of the

Table 2 Influence of cheese extracts permeates lyophilisates addition on the growth of $L$. innocua LRGIA 01 growth at $30^{\circ} \mathrm{C}$ in $\mathrm{BHI}$ broth

\begin{tabular}{llll}
\hline Cheese & Asiago d'Allevo & \multicolumn{2}{c}{ Emmental de Savoie } \\
\cline { 2 - 4 } Age (days) & 150 & 97 & 114 \\
\hline Proportion (\%) of reduction of OD 600 after 12-h incubation & $58 \pm 1^{\mathrm{a}}$ & $61 \pm 1^{\mathrm{a}}$ & $26 \pm 2^{\mathrm{b}}$ \\
Proportion (\%) of reduction of growth rate & 60 & 46 & 91
\end{tabular}

Cheese extracts permeates contain molecules with a molecular mass ranging from $\sim 100-500$ to $\sim 1,000$ g.mol ${ }^{-1}$

Samples with same letters are not significantly different $(P<0.05)$. The results presented are the means of three replicates \pm standard error of the mean 
total antimicrobial activity of Emmental de Savoie cheese ripened for 97 days and of Asiago cheese ripened for 150-days extracts, respectively, while this percentage of contribution was only $42 \pm 3 \%$ in the case of Emmental de Savoie cheese ripened for 114 days. This latter difference was not observed when comparing maximal growth specific rate reductions induced by addition of cheese extracts filtrates and whole cheese extracts: similar results were observed whatever the cheese sample. It can thus be concluded that $L$. innocua growth inhibition was mainly due to peptides with a molecular mass lower than 1,000 g. $\mathrm{mol}^{-1}$. This indicates that the observed antimicrobial activity cannot only be ascribed to intact bacteriocins, known to present a molecular mass exceeding 3,000 g.mol ${ }^{-1}$ (Drider et al. 2006). The hypothesis of the contribution of fragments of caseins is thus more likely. Identified antimicrobial fragments of caseins reviewed by Silva and Malcata (2005) were reported to have a molecular mass varying from 400 to 6,000 g.mol ${ }^{-1}$. The largest antimicrobial fragments of caseins, such as isracidin $\left(\alpha_{\mathrm{s} 1} \mathrm{CN} \mathrm{f}(1-23)\right.$, average mass $=2,764.23 \mathrm{~g} \cdot \mathrm{mol}^{-1}$ and theoretical $\mathrm{pHi}=9.99$ as calculated from PeptideMass software on expasy.org) or casocidin-I ( $\alpha_{\mathrm{s} 2} \mathrm{CN} \mathrm{f}(150-188)$, average mass $=4,869.69$ g. $\mathrm{mol}^{-1}$ and theoretical $\mathrm{pHi}=10.08$ ) were thus absent from ultrafiltrated cheese extracts, which still strongly inhibited L. innocua growth. This is consistent with the study of Lignitto et al. (2012) who observed that the concentration of these two peptides in Asiago cheeses was not correlated with their anti-Listeria activity. Therefore, they suggested that anti-Listeria activity of Asiago cheese extracts was likely also due to other peptides. The present results strongly suggest that these other peptides likely have a molecular mass lower than 1,000 g.mol ${ }^{-1}$. The studies regarding the size of antibacterial peptides in cheeses are scarce. Pritchard et al. (2010) compared the antibacterial activity of three Cheddar extracts containing peptides with a molecular mass lower than 5,000 or 10,000 g.mol ${ }^{-1}$ or exceeding 10,000 g.mol ${ }^{-1}$. In contrast to

Table 3 Influence of addition of CEC fractions of Asiago cheese water-soluble extract lyophilisates on the growth of L. innocua LRGIA 01 at $30^{\circ} \mathrm{C}$ in BHI broth

\begin{tabular}{|c|c|c|c|}
\hline & $\begin{array}{l}\text { Fraction } \\
\text { I }\end{array}$ & $\begin{array}{l}\text { Fraction } \\
\text { II }\end{array}$ & $\begin{array}{l}\text { Fraction } \\
\text { III }\end{array}$ \\
\hline $\begin{array}{l}\text { Proportion (\%) of mass of Asiago cheese lyophilisate initially loaded } \\
\text { on CEC column* }(w / w)\end{array}$ & 26 & 49 & 25 \\
\hline Proportion $(\%)$ of reduction of maximal $\mathrm{OD}_{600}$ & $9 \pm 1^{\mathrm{a}}$ & $31 \pm 4^{\mathrm{b}}$ & $34 \pm 1^{\mathrm{b}}$ \\
\hline Proportion $(\%)$ of reduction of growth rate & 48 & 82 & 72 \\
\hline $\begin{array}{l}\text { Proportion }(\%) \text { of peptides with a molecular mass between } 200 \text { and } \\
1,000 \text { g.mol }{ }^{-1} \text { in cheese extracts* }\end{array}$ & 49 & 87 & 74 \\
\hline $\begin{array}{l}\text { Proportion (\%) of peptides with a molecular mass between } 1,000 \text { and } \\
10,000 \mathrm{~g} \cdot \mathrm{mol}^{-1} \text { in cheese extracts* }\end{array}$ & 51 & 13 & 26 \\
\hline
\end{tabular}

Samples with same letters are not significantly different $(P<0.05)$. The results presented are the means of 3 replicates \pm standard error of the mean

*The respective proportions of peptides having a molecular comprised between 200 and 1,000, and 1,000 and 10,000 g.mol ${ }^{-1}$ were estimated by analysing the chromatograms obtained following the injection of cheese extracts onto a calibrated gel filtration chromatography Superdex PeptideTM column, assuming that the areas of peaks resulting from the elution of molecules absorbing at $215 \mathrm{~nm}$ corresponded to peptides and were proportional to their mass concentration 
what we observed when fractionating Emmental de Savoie and Asiago cheeses extracts, the highest inhibition of Escherichia coli and Bacillus cereus growth was exerted by extracts containing high molecular mass peptides (exceeding 10,000 g.mol ${ }^{-1}$ ).

\subsection{L. innocua growth inhibitory activity of CEC fractions of Asiago cheese WSE}

Although antimicrobial casein fragments identified to date have a high diversity of structure, most of them are cationic. Therefore, Asiago cheese extract was separated into three fractions onto a column filled with a strong cation exchanger. The fraction I contained molecules which were rapidly eluted (likely non-cationic peptides which did not interact with the chromatographic support). The fraction II corresponded to molecules eluted just thereafter and before the beginning of the linear salt gradient applied to elute cationic peptides more strongly interacting with the chromatographic support. The molecules eluted during salt gradient application were pooled in fraction III. The respective proportions of molecules present in the three fractions as well as their L. innocua cells growth inhibitory activities are given in Table 3.

When resuspended in BHI broth at the same concentration $\left(20 \mathrm{mg} \cdot \mathrm{mL}^{-1}\right)$, all fractions significantly inhibited L. innocua LRGIA01 cells growth. However, fractions II and III reduced both maximal $\mathrm{OD}_{600}$ as well as maximal specific growth rate far more than fraction I (by 82, 72 and $48 \%$, respectively). This suggests thus that L. innocua cells growth is more inhibited by cationic peptides than by non-cationic peptides extracted from Asiago cheese. The cationic nature of numerous antimicrobial peptides is due to the facts that their initial contact with the target bacteria is electrostatic and that most bacterial surfaces are anionic (Powers and Hancock 2003). Moreover, the GFC analysis of molecular mass distribution (Table 3 ) indicates that the two most active fractions (II and III) mainly contain peptides with a molecular mass between 200 and 1,000 g.mol ${ }^{-1}$. This is consistent with the previous observation that Asiago cheese extract anti-L. innocua activity was mainly due to peptides with a molecular mass lower than 1,000 g.mol ${ }^{-1}$. However, ultrafiltering onto 1,000 g.mol ${ }^{-1}$ cut-off membrane and testing antimicrobial activity of fraction II permeate would be necessary to assess the validity of this statement.

\subsection{Characterisation of cheeses and their extracts}

Several authors reported that the antibacterial activity of cheese extracts is due to casein fragments. As a consequence, they observed that proteolysis accompanying cheese ripening strongly influences the antibacterial activity of cheese extracts. Therefore, proteolysis of the four cheeses was characterised by measuring the WSN/TN ratio and by assessing the proportion of molecules with a molecular mass between 200 and 1,000 g.mol ${ }^{-1}$ in cheese WSEs by GFC analysis (Table 4). WSN/TN ratio of Asiago cheese ripened for 150 days was equal to $22.8 \%$ and WSN/TN ratios of Emmental de Savoie cheeses ripened between 97 and 149 days were quite similar (comprised between $23.0 \%$ and $26.6 \%$ ). WSN/TN of a given cheese increases throughout ripening, however in the present study three different Emmental de Savoie cheeses were sampled out in different cheesemaking plants: the 


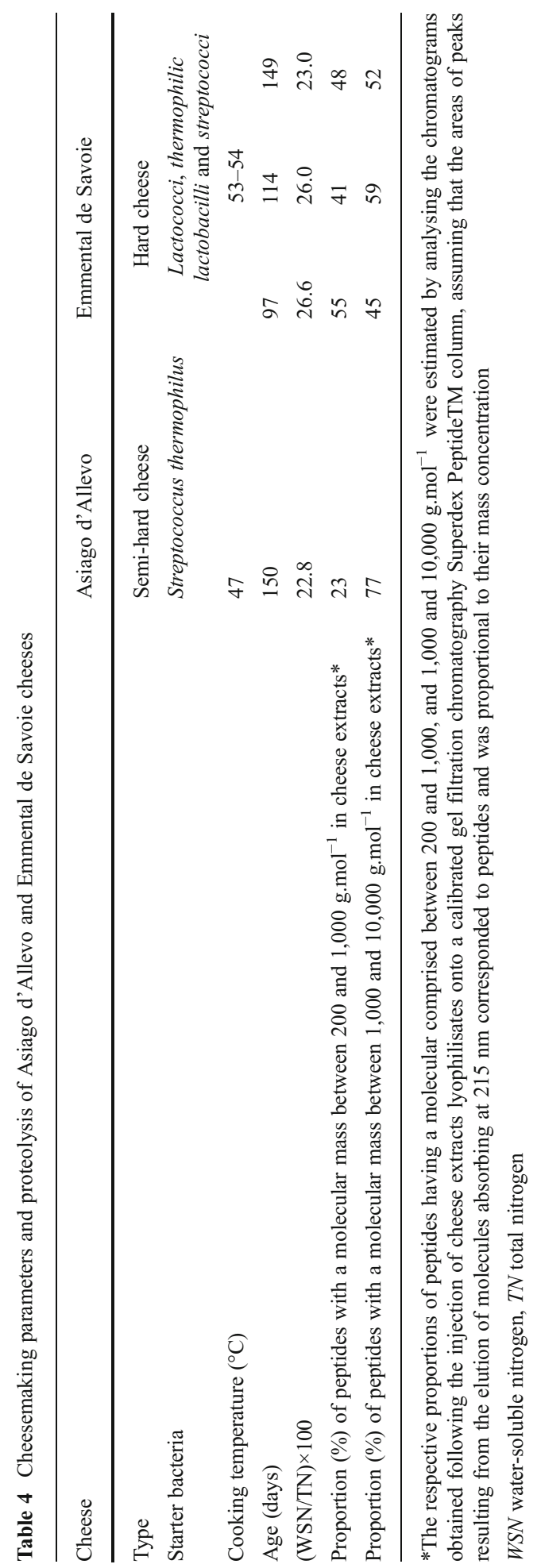


differences regarding milk, cheesemaking and ripening conditions can thus explain that the cheese with the highest WSN/TN ratio (26.6\%) was ripened for 97 days, while that with the lowest WSN/TN ratio (23.0\%) was ripened for 149 days. Rizzello et al. (2005) noticed that cheeses ripened for a short or medium time contained antibacterial peptides, while those having longer ripening periods such as Parmigiano-Reggiano cheese did not: they suggested that the antimicrobial fragments of caseins released by proteolytic enzymes would be further degraded into inactive fragments when proteolysis exceeded a certain level. More generally, they considered that cheeses containing the highest amount of bioactive peptides had a WSN/TN ratio that ranged from $12 \%$ to $24 \%$. However, since WSN is heterogeneous, further characterisation of the composition of WSN is necessary when studying cheese proteolysis. Therefore, WSEs of each cheese were analysed by GFC. This allowed to observe that while between $41 \%$ and $55 \%$ of peptides present in Emmental de Savoie cheese WSE had a molecular mass between 200 and 1,000 g.mol ${ }^{-1}$, these peptides accounted for $23 \%$ in Asiago cheese WSE, while the four cheese samples analysed had almost the same WSN/TN ratio. This is consistent with the known respective characteristics of semi-hard and hard cheeses. The secondary proteolysis in hard cheeses is known to be far more intense: the large- and medium-size peptides resulting from primary proteolysis of caseins are rapidly degraded into oligopeptides and free amino acids. In semi-hard cheeses, secondary proteolysis is less intense and as a consequence more large- and medium-size peptides can accumulate in the watersoluble fraction of these cheeses. In the present study, it is noteworthy that while peptides with a molecular mass lower than 1,000 g.mol ${ }^{-1}$ represented $23 \%$ of peptides of Asiago cheese WSE, they accounted for $100 \pm 2 \%$ of its inhibitory activity of L. innocua growth.

\section{Conclusion}

Peptides present in Emmental de Savoie cheeses were found to significantly inhibit $L$. innocua and L. monocytogenes growth. Moreover, most of the peptides inhibiting $L$. innocua present in Emmental de Savoie cheeses as well as the Asiago cheese tested in this study had a molecular mass lower than 1,000 g.mol ${ }^{-1}$. This indicates that the observed anti-Listeria activity cannot be ascribed to intact bacteriocins and is more likely due to low molecular mass antimicrobial fragments of caseins. In order to get further insight in the structural characteristics of the peptides inhibiting L. innocua present in Asiago cheese, they were fractionated by CEC. The fraction containing non-cationic peptides had a lower antimicrobial activity than the fractions containing cationic peptides, suggesting thus that cationic peptides significantly contributed to the observed effect. Further fractionation by different chromatographic techniques including CEC will thus be performed to identify the antibacterial peptides present in the two Alpine cheeses.

Acknowledgments The Emmental de Savoie cheese samples were provided by Actilait. The authors would like to thank Conseil Général de l'Ain and Communauté d'Agglomération de Bourg en Bresse for their financial support. The authors are finally very grateful to Agence Universitaire de la Francophonie for the PhD grant of Phuong NGUYEN THI. 


\section{References}

AOAC (U.S.) (1984) Official methods of analysis of the Association of Official Analytical Chemists (14th edition). Washington DC, USA

Bouton Y, Guyot P, Dasen A, Grappin R (1993) Activité protéolytique de souches de lactobacilles thermophiles isolées de levains et de Comté. I. Validation sur minifromages des techniques de laboratoire. [Proteolytic activity of thermophilic Lactobacillus strains isolated from sourdough starters and Comté cheese. I. Laboratory techniques validation using minicheeses]. Le Lait 73:265-279

Drider D, Fimland G, Héchard Y, McMullen LM, Prévost H (2006) The continuing story of class IIa bacteriocins. Microbiol Mol Biol Rev 70:564-582

Dupas C, Adt I, Cottaz A, Boutrou R, Mollé D, Jardin J, Jouvet T, Degraeve P (2009) A chromatographic procedure for semi-quantitative evaluation of caseinphosphopeptides in cheese. Dairy Sci Technol 89:519-529

Gagnaire V, Léonil J (2002) Emmental cheese as a source of bioactive peptides. World Dairy Congress: Congrilait September 24-27th, Paris

Gobbetti M, Stepaniak L, De Angelis M, Corsetti A, Di Cagno R (2002) Latent bioactive peptides in milk proteins: proteolytic activation and significance in dairy processing. Crit Rev Food Sci Nutr 42:223-239

Kamat AS, Nair PM (1996) Identification of Listeria innocua as a biological indicator for inactivation of $L$. monocytogenes by some meat processing treatments. LWT Food Sci Technol 29:714-720

Lignitto L, Segato S, Balzan S, Cavatorta V, Oulahal N, Sforza S, Degraeve P, Galaverna G, Novelli E (2012) Preliminary investigation on the presence of peptides inhibiting the growth of Listeria innocua and Listeria monocytogenes in Asiago d'Allevo cheese. Dairy Sci Technol 92:297-308

Powers J-PS, Hancock RE (2003) The relationship between peptide structure and antibacterial activity. Peptides 24:1681-1691

Pritchard SR, Phillips M, Kailasapathy K (2010) Identification of bioactive peptides in commercial Cheddar cheese. Food Res Int 43:1545-1548

Rizzello CG, Losito I, Gobbetti M, Carbonara T, De Bari MD, Zambonin PG (2005) Antibacterial activities of peptides from the water-soluble extracts of Italian cheese varieties. J Dairy Sci 88:2348-2360

Rodriguez E, Gaya P, Nunez M, Medina M (1998) Inhibitory activity of a nisin-producing starter culture on Listeria innocua in raw ewes milk Manchego cheese. Int J Food Microbiol 39:129-132

Segato S, Balzan S, Elia CA, Lignitto L, Granta A, Magro L, Contiero B, Andrighetto I, Novelli E (2007) Effect of period of milk production and ripening on quality traits of Asiago cheese. Ital J Anim Sci 6(suppl 1):469_ 471

Silva SV, Malcata FX (2005) Caseins as source of bioactive peptides. Int Dairy J 15:1-15 